International Journal of Biological Research, $2(2)(2014) 131-133$
International Journal of Biological Research
Journal home page: $\begin{gathered}\text { www.sciencepubco.com/index.php/IJBR } \\ \text { doi: } 10.14419 / \text { ijbr.v2i2.3515 } \\ \text { Research Paper }\end{gathered}$

\title{
Studies on the antimicrobial potency of the marine algae - Caulerpa scalpelliformis and Spyridia species
}

\author{
Mrinalini.J.Singh \\ Research Scholar, Department of Botany, Nirmala College for Women, Coimbatore 641 018, Tamil Nadu, India \\ E-mail: mrinalini.singh50@gmail.com
}

\begin{abstract}
Objective: To study the antimicrobial potency of the marine algae - Caulerpa scalpelliformis and Spyridia sp.

Methods: Caulerpa scalpelliformis and Spyridia sp. were screened for the presence of bioactive components by extracting them with suitable solvents and studying their antimicrobial activities against varied human pathogens. An attempt has also been made to separate the unknown compounds using Thin Layer Chromatography and purify the extracts using column chromatography since not much work has been carried out in these species.

Results: In Spyridia, only the methanolic extract could produce zone of inhibition against Staphylococcus aureus and Salmonella sp. whereas in Caulerpa scalpelliformis, only the petroleum ether, chloroform and methanolic extracts showed antimicrobial properties. Better resolution was found in the mobile phase containing chloroform: methanol 80: 20 ratio for Caulerpa. Hence, its methanolic extract was fractioned in silica gel column and these fractions were effective against some of the test organ-isms but not against all.

Conclusion: Further investigation is required to study the nature of compounds with antimicrobial properties with reference to Caulerpa scalpelliformis; whereas with Spyridia sp. the study can be extracted to collect the samples during different seasons of a year and confirm its antimicrobial potency.
\end{abstract}

Keywords: Caulerpa Scalpelliformis, Spyridia SP, Antimicrobial Activities, Thin Layer Chromatography, Column Chromatography.

\section{Introduction}

Marine algae or seaweeds are salt water dwelling, containing various pigments and are attached by hold fasts to anchor them. They are rich in bioactive natural products and have been studied as potential biocides and pharmaceutical agents (Abbott et al., 2002). Among the seaweeds group, the members of green and red marine algae are of great economic importance. The main products of red seaweeds are agar-agar and carrageen used mostly in baking, and as an emulsifying agent in pharmaceutical industry.

Due to the emergence of commercial drug resistant organisms with enhanced side effects, there is a need for the discovery of new drugs. Marine algae seem to be the treasure house of natural bioactive secondary metabolites with high therapeutic potency and no side effects. Despite this, the number of seaweed species studied and identified corresponds to only $2 \%$ of the 150,000 known species worldwide (Harvey et al., 1988). From the species identified, approximately two thousand chemical compounds have been characterized (González \& Silva. 2001). Various systematic works have been carried out on marine algal extracts worldwide for antimicrobial, anticancerous, anti-inflammatory and antioxidant studies with no side effects.

Hence, the objective of this study was to evaluate the antibacterial activities of the organic extracts from two marine algae Caulerpa sp and Spyrida sp collected from the South Eastern coastal areas of Tamil Nadu.

\section{Materials and methods}

\subsection{Sample collection}

About $1 \mathrm{~kg}$ of the two species of seaweeds namely Caulerpa $\mathrm{sp}$ and Spyrida sp were collected fresh from the south east coast of Tamil Nadu (Rameshwaram) during the month of December, 2007. Cleaning and drying of the samples were performed as mentioned by Pereira et al., 2003. The washed samples were shade dried, powdered and stored in sterile containers under refrigeration until use.

Extraction of hundred grams of powdered biomass with solvents of increasing polarity ranging from petroleum ether to water through benzene, chloroform, ethyl acetate and methanol for 72 hours at room temperature with intermittent stirring for every twenty four hours was made in succession.

Strains used for testing antimicrobial activity were Staphylococcus aureus (MTCC, 740), Salmonella typhimurium (MTCC, 98), Escherichia coli (GM242) and Candida albicans (MTCC, 227). The remaining isolates such as Klebsiella sp, Proteus sp, Citrobacter sp and Pseudomonas sp were collected from PSG Institute of Medical Science \& Research, Coimbatore.

Around $100 \mu \mathrm{l}$ of all the extracts thus were injected into empty sterilized filter paper disc having a diameter of $5 \mathrm{~mm}$. The discs impregnated with the mother solvents of each extracts served as the control and were placed on the same plate. Antimicrobial activities of algal extracts were tested separately using disc diffusion method (Bauer et al., 1966).

Thin layer chromatography of each sample was performed on Merck TLC F254 plates, with Chloroform: Methanol in the ratio 
of varying concentrations such as 10: 90, 80:20, 20:80 and 90:10 as mobile phase. The separated components were visualized under ultraviolet light of $254 \mathrm{~nm}$.

Purification of the crude extracts was carried out as per the procedure of Vairappan et al., 2001 with few modifications. The seaweed extracts with antibacterial activity were fractionated by silica gel column chromatography (chloroform and methanol).The fractions were eluted with chloroform: methanol and were further subjected to antimicrobial assay and Thin layer chromatography.

\section{Result}

Table 1: Antimicrobial Activity from Various Extracts of Spyridia Sp.

\begin{tabular}{|c|c|c|c|c|c|}
\hline \multirow[b]{2}{*}{$\begin{array}{l}\text { Test Organ- } \\
\text { isms }\end{array}$} & \multicolumn{5}{|c|}{ Zone of Inhibition (mm) } \\
\hline & $\begin{array}{l}\text { Petrole- } \\
\text { um ether }\end{array}$ & $\begin{array}{l}\text { Ben- } \\
\text { zene }\end{array}$ & $\begin{array}{l}\text { Chloro- } \\
\text { form }\end{array}$ & $\begin{array}{l}\text { Ethyl } \\
\text { ace- } \\
\text { tate }\end{array}$ & $\begin{array}{l}\text { Metha- } \\
\text { nol }\end{array}$ \\
\hline $\begin{array}{l}\text { Escherichia } \\
\text { coli }\end{array}$ & - & - & - & - & - \\
\hline $\begin{array}{l}\text { Staphylococ- } \\
\text { cus aureus }\end{array}$ & - & - & - & - & 7.5 \\
\hline $\begin{array}{l}\text { Citrobacter } \\
\text { sp. }\end{array}$ & - & - & - & - & - \\
\hline Klebsiella sp. & - & - & - & - & - \\
\hline $\begin{array}{l}\text { Pseudomonas } \\
\text { sp. }\end{array}$ & - & - & - & - & - \\
\hline Proteus sp. & - & - & - & - & - \\
\hline $\begin{array}{l}\text { Salmonella } \\
\text { sp. }\end{array}$ & - & - & - & - & 9.4 \\
\hline $\begin{array}{l}\text { Candida } \\
\text { albicans }\end{array}$ & - & - & - & - & - \\
\hline
\end{tabular}

Table 2: Antimicrobial Activity from Various Extracts of Caulerpa scalpelliformis

\begin{tabular}{|c|c|c|c|c|c|}
\hline \multirow[b]{2}{*}{$\begin{array}{l}\text { Test Organ- } \\
\text { isms }\end{array}$} & \multicolumn{3}{|c|}{ Zone of Inhibition (mm) } & \multirow[b]{2}{*}{$\begin{array}{l}\text { Ethyl } \\
\text { ace- } \\
\text { tate }\end{array}$} & \multirow[b]{2}{*}{$\begin{array}{l}\text { Metha- } \\
\text { nol }\end{array}$} \\
\hline & $\begin{array}{l}\text { Petrole- } \\
\text { um ether }\end{array}$ & $\begin{array}{l}\text { Ben- } \\
\text { zene }\end{array}$ & $\begin{array}{l}\text { Chloro- } \\
\text { form }\end{array}$ & & \\
\hline $\begin{array}{l}\text { Escherichia } \\
\text { coli }\end{array}$ & 8 & - & 10 & - & 8 \\
\hline $\begin{array}{l}\text { Staphylococ- } \\
\text { cus aureus }\end{array}$ & - & - & - & - & - \\
\hline $\begin{array}{l}\text { Citrobacter } \\
\text { sp. }\end{array}$ & - & - & 8 & - & 10 \\
\hline Klebsiella $\mathrm{sp}$. & 9 & - & - & 7 & 8 \\
\hline $\begin{array}{l}\text { Pseudomonas } \\
\text { sp. }\end{array}$ & - & - & - & 8 & 8 \\
\hline Proteus sp. & - & - & - & - & - \\
\hline $\begin{array}{l}\text { Salmonella } \\
\text { sp. }\end{array}$ & - & - & - & - & - \\
\hline $\begin{array}{l}\text { Candida } \\
\text { albicans }\end{array}$ & - & - & - & - & 9 \\
\hline
\end{tabular}

In order to survive in a highly competitive environment marine algae have to develop defense strategies that results in a tremendous diversity of compounds from a different metabolic pathway. Recent trends in drug research from natural sources have shown that the algae are promising organisms to furnish novel biochemically active compounds. The bioactive substances from seaweed have great chances to be employed against bacteria, viruses, other pathogens and tumors (Cragg et al., 1997).

The crude extracts were used to study their antimicrobial properties with the test organisms. In Spyridia, only the methanolic extract could produce zone of inhibition against Staphylococcus aureus and Salmonella sp. (Table 1) whereas in Caulerpa scalpelliformis, only the petroleum ether, chloroform and methanolic extracts of Caulerpa scalpelliformis showed antimicrobial properties (Table 2).

Thin layer chromatography was performed to find out a better separation of compounds using various combinations of chloroform and methanol and a better resolution was found in the mobile phase containing chloroform: methanol 80: 20 ratio. The methanolic extract of Caulera scalpellifomis was fractioned in silica gel column. The elutions were collected at regular intervals and were checked for their antimicrobial properties. The fractions were effective against some of the test organisms but not against all (Table 3).

Table 3: Antimicrobial Activity of Partially Purified Methanol Extract through Silica Gel Column Chromatography from Caulerpa Scalpelliformis

\begin{tabular}{|c|c|c|c|c|c|c|c|c|c|}
\hline \multirow[t]{2}{*}{$\begin{array}{l}\text { Test } \\
\text { organisms }\end{array}$} & \multicolumn{9}{|c|}{ Zone of inhibition(mm) } \\
\hline & 1 & 2 & 3 & 4 & 5 & 6 & 7 & 8 & 9 \\
\hline E. coli & - & 10 & 11 & 10 & 10 & - & - & 10 & - \\
\hline $\begin{array}{l}\text { Staph. } \\
\text { aureus }\end{array}$ & 10 & 10 & - & - & - & 10 & 11 & 10 & 10 \\
\hline $\begin{array}{l}\text { Citrobacter } \\
\text { sp. }\end{array}$ & 9 & 8 & 8 & - & 8 & 10 & - & - & - \\
\hline $\begin{array}{l}\text { Klebsiella } \\
\text { sp. }\end{array}$ & - & - & - & 10 & 8 & 8 & 8 & - & 8 \\
\hline $\begin{array}{l}\text { Pseudomonas } \\
\text { sp. }\end{array}$ & - & - & - & - & - & - & - & 10 & 8 \\
\hline Proteus sp. & - & - & - & 9 & - & - & - & - & - \\
\hline $\begin{array}{l}\text { Salmonella } \\
\text { sp. }\end{array}$ & - & - & - & - & - & - & - & 9 & - \\
\hline $\begin{array}{l}\text { Candida } \\
\text { albicans }\end{array}$ & 10 & 9 & - & - & 10 & - & - & - & - \\
\hline
\end{tabular}

In the crude methanolic extract, effect was observed against all the test cultures whereas none of the eluted fractions could inhibit few test cultures.

\section{Discussion}

The probable reasons attributed to this are one single compound was not sufficient to inhibit the growth of these cultures. This could further be supported but the presence of antimicrobial compounds in various fractions. The genus Caulerpa is represented by nearly 60 species. Several reports are available on the metabolic of various other species of Caulerpa. No reports in this regard are available on the antibacterial compounds of C. scalpelliformis. Hence further purification and structure analysis only could answer the above mystery of none of the fractions inhibiting few test cultures.

Finally it could be concluded that the $C$. scalpelliformis is a potential source of natural antibiotics.

\section{Conclusion}

In this paper, we have reported the antimicrobial properties of bioactive components extracted from the marine algae Caulerpa scalpelliformis and Spyridia sp. Further investigation is required to study the nature of compounds with antimicrobial properties with reference to Caulerpa scalpelliformis; whereas with Spyridia sp. the study can be extracted to collect the samples during different seasons of a year and confirm its antimicrobial potency. Intensive studies must be carried out to unravel its unexhausted reserve of bio-metabolites.

\section{Conflict of Interest Statement}

We hereby declare that we have no conflict of interest.

\section{Acknowledgement}

I am thankful to the authorities of Microbiology Department especially Late Mrs. C.K. Raadha in PSG College of Arts and Science, Coimbatore, Tamil Nadu for providing necessary facilities to perform the experiment. 


\section{References}

[1] Abbott, I.A., Fisher, J. Mc Dermid, K.J. (2002). New re-ported and revised marine algae from the Nha Trang,Vietnam, in: taxonomy of economic seaweed with reference to some pacific species. Oceanographic Institute Nha Trang Vietnam 8:291-321

[2] Harvey SC, J Luo \& R Lavery. (1988). DNA stem-loop structures in oligopurine-oligopyrimidine triplexes. Nucleic Acids Research 16(24): 11795-11809. http://dx.doi.org/10.1093/nar/16.24.11795.

[3] González F \& M Silva. (2001). Biodiversidad química de macroalgas marinas. In: Alveal $\mathrm{K} \& \mathrm{~T}$ Antezana (eds). Sustentabilidad de la biodiversidad, unproblema actual. Bases científico-técnicas, teorizaciones y proyecciones, and pp. 415-496. Universidad de Concepción, Concepción.

[4] Pereira R.C., B.A.P. DaGama, V.L. Teixeira and Y. YoneshigueValentin (2003). Ecological roles of natural products of the Brazilian red seaweed Laurencia obtuse. Braz.J.Biol 63(4):665-672. http://dx.doi.org/10.1590/S1519-69842003000400013.

[5] Bauer,A.W., W.M.Kirby, J.C.Scheris and M.Truck (1966). Antibiotic susceptibility testing by standardization by single disc method.Amer.J.Clinical Pathol 45:493-496.

[6] Vairappan C. S., Suzuki, M., Abe T., Masuda, M. (2001). Halogenated metabolites with antibacterial activity from the Okinawa, Laurencia sp phytochemistry 58: 517-523.

[7] Cragg, G. M., Newman and K. M. Snader, (1997). Natural products in drug discovery and development J.Nat prod 60: 52-60. http://dx.doi.org/10.1021/np9604893. 